EISSN: 2706-7955 ISSN: 2077-4605

DOI: 10.36632/mejar/2021.10.4.71

Journal homepage: www.curresweb.com

Pages: 1055-1062

\title{
Irrigation Intervals and Grazing Intensity Induced Variations in Growth and Chemical Components of Periploca Angustifolia (Labill) Grown In North Sinai
}

\author{
El-Houssini A.A. ${ }^{1}$, El-Henawy A.A. ${ }^{2}$, El Shesheny M. A. ${ }^{1}$ and Abd El-Maboud M. M. ${ }^{2}$ \\ ${ }^{I}$ Plant Ecology \& Range Management Dept., Range Management Unit, Desert Research Center, Cairo, \\ Egypt \\ ${ }^{2}$ Plant Ecology \& Range Management Dept., Eco- Physiology Unit, Desert Research Center, Cairo, \\ Egypt
}

\author{
Received: 11 August $2021 \quad$ Accepted: 05 Oct. 2021 Published: 15 Oct. 2021
}

\begin{abstract}
Two field trials were conducted in the experimental farm of Baloza Research Station, located at North Sinai. The objective of this study was to evaluate the effects of irrigation intervals (2, 3 and 4 weeks) and cutting heights (30 and $60 \mathrm{~cm}$ above the ground surface) on growth parameters and chemical contents of Periploca angustifolia (Labill) plants. Obtained results indicated that most of growth parameters were decreased in response to various irrigation intervals. Carbohydrates, lipids and $\mathrm{K}$ contents (in leaves) were decreased due to irrigation intervals, while the reverse was observed in protein. On the other hand, carbohydrate and $\mathrm{K}$ contents in stems were increased as irrigation intervals increased while the reverse was true in protein, lipids and ash contents. No changes were found in various growth parameters with increasing cutting height from 30 to $60 \mathrm{~cm}$ except in plant dry weight in the first and second cut, fresh weight and leaf area in the second cut which were decreased with increasing cutting height. With increasing cutting height, carbohydrate was higher; nevertheless, protein and $\mathrm{K}$ were lower in leaves. In the opposite side, carbohydrate was lower while protein and lipids were higher at $60 \mathrm{~cm}$ cutting in stem.
\end{abstract}

Keywords: Periploca angustifolia, irrigation intervals, growth parameters, chemical contents

\section{Introduction}

Coastal Mediterranean Region particularly arid and semi-arid parts has a range history of intensive land - use, mainly for grazing and rain fed farming (Heneidy, 2002). In Egypt, pressure on improper management practices has led to shortages and poor quality of forage for animal production (ElHoussini 2007).

Periploca angustifolia (Labill) is a multipurpose xerophytic shrub widely distributed in arid zones. It is a Mediterranean Saharan element growing wild in low and middle Mediterranean basin and descends in southwards to northern and central Sahara. It is found in North Africa from Morocco to Egypt (Pietro and Maurizio 2012). P. angustifolia is an autochthonous species of the Mediterranean region; it is well adapted to arid climates and has a high pastureland ecological value (Ferchichi, 1995). Its leaves and stems can provide suitable feed for ruminants, which may graze the standing plants, $P$. angustifolia is a highly adoptable plant, and classified as a species well adopted to semi-arid regions, largely because of its ability to tolerant dry conditions.

$P$. angustifolia is also a feeding resource for livestock (Castro et al., 2002). This plant is a multipurpose shrub used to rehabilitate dry lands. Reiad et al., (2001) pointed out that forage yield of pigeon pea whole plant, leaves and stems showed an increase in relation to raising cutting height. Furthermore, El-Houssini et al., (2002) on Atriplex Canescens mentioned that all the studied growth parameters were responded insignificantly to varying cutting height in the first season. However, in the second one crown cover and both fresh and dry forage weight / shrub were increased significantly by raising stubble height from 25 to $75 \mathrm{~cm}$.

Corresponding Author: El-Houssini A.A., Plant Ecology \& Range Management Dept., Range Management Unit, Desert Research Center, Cairo, Egypt 
Concerning irrigation intervals, Kheraishi et al., (2004) to study the effect of irrigation intervals on Kochia indica forage yield and growth parameters, they found that the highest values of most growth criteria were achieved when the plants were irrigated every 4 weeks compared to these were irrigated every 2 or 6 weeks. Also, Dghim et al. (2018) found that withholding water until three weeks caused a reduction in chlorophyll a, transpiration and osmotic potential, nevertheless, increased soluble sugars and proline as compared to control in P. angustifolia.

Abd El-Maboud et al. (2018) studied the biochemical responses of $P$. angustifolia to water stress. They found that all vegetative parameters were attained the highest reading at $160 \mathrm{~mm} /$ year irrigation amount. Also, they mentioned that $P$. angustifolia is a drought tolerant plant that can adapt morphologically to water stress by reducing its growth parameters to reduce transpiration process. Furthermore, Reiad et al, (2005) found that prolonging or shortening irrigation intervals than four weeks tended to cut down forage yield of Kochia indica plants.

Domestication and cultivation such new forage plant with high nutritive value and high yielding capacity as will as wide adaptability in regard to the environmental and edaphic conditions may compensate the severe deficient in forage production.

\section{Material and Methods}

Two field experiments were carried out at Baloza Research Station farm of Desert Research Center located at North Sinai, Egypt during 2 successive growing seasons (2017/2018 and 2018/2019). The soil at the experimental site is characterized as sandy texture, ( $94 \%$ sand, $5.5 \%$ silt and $0.5 \%$ clay).

Each experiment included 6 treatments which were the combinations of three irrigation intervals (2, 3 and 4 weeks) and two cutting heights (30 and $60 \mathrm{~cm}$ above the ground surface). Seeds of $P$. angustifolia were collected from natural population from west Sidi Barrani city and sown in polyethylene bags filled with sand and clay soil $(1: 1)$ under temperature and humidity controlled conditions in greenhouse. Six months later, uniform and healthy seedlings were transplanted in the permanent site. Seedlings were planted in rows $1 \mathrm{~m}$ apart and spaced $1 \mathrm{~m}$ between seedlings within each row. Plants were regularly irrigated two weeks by interval. After good establishment with shrub two years old, the cutting management was stated in two cutting height i.e. 30 and $60 \mathrm{~cm}$ were applied and three irrigation intervals viz. two weeks, three weeks and four weeks were used. Six treatments that the combinations between three irrigation intervals and two cutting heights were arranged in Split-plot design with 3 replications. The main plots were devoted to irrigation intervals and the sub plots were occupied by cutting heights.

Some growth parameters via plant height $(\mathrm{cm})$, no. of branches/plant, leaf area $(\mathrm{cm} 2)$, crown cover (m2) and crown volume (m3)were measured (average of five plants was taken ) and calculated as following formulas reported by Thalen (1978).

Crown cover $=1 / 4$ Л $\times$ D $1 \times$ D2

Crown volume $=1 / 6$ Л $\times$ D $1 \times$ D $2 \times \mathrm{H}$

Where, Л $=3.14, \mathrm{D} 1$ and $\mathrm{D} 2=$ the two diameters, $\mathrm{H}=$ plant height.

Total chlorophyll was assayed using Mino LTA/ chlorophyll meter SPAD-502-Mimolata Co. LTD. Japan.

Samples from leaves and stems were dried by oven at 60c till constant weight, then ground to fine powder material and used for chemical analysis.

Crude protein was determined through the multiplying of total nitrogen values with the factor 6.25 using Micro- kjeldahl method (Tripathi et al., 1971). Total lipids was extracted with equal volume from ether and petroleum ether using soxhelet apparatus and calculated as lipid content $\%=$ mass of lipid extracted $(\mathrm{g}) /$ sample weight $(\mathrm{g}) \times 100$. Total ash content of the dry plant materials was determined after ignition at $500^{\circ} \mathrm{C}$ in a muffle furnace for $6 \mathrm{~h}$, and calculated as in AOAC (1990). Potassium was measured in acid digested samples by flame photometer as described by Yoshida et al., (1976).

Data obtained were exposed to the proper statistical analysis of variance according to Snedecor and Cochran (1980). Means followed by the same alphabetical letter(s) are not statistically different at the 0.05 level of significance according to Duncan's new multiple range test (Duncan, 1955). 


\section{Results and Discussion}

\subsection{Effect of irrigation intervals on vegetative growth parameters and total chlorophyll}

Influence of irrigation intervals on growth characters of in the two years of experiment are represented in Table (1). Most of the tested growth parameters are decreased with increasing irrigation intervals from two weeks to four weeks. Such decrements were only significant for number of branches per plant at first and second cut, leaf area and total chlorophyll in the second one. The reduction in chlorophyll content with drought is in harmony with those obtained by Abd El-Maboud (2016), Dghim et al. (2018). The reduction of photosynthetic activity under drought stress owing to an imbalance between light capture and it's utilization (Foyer and Noctor, 2000).

Data in Table (1) showed the differences between means of plant height and crown volume due to irrigation intervals were not great enough to reach the significance level. This effect was true in all cuts taken. In this concern, Kheraishi et al., (2004) stated that the highest values of most growth criteria were achieved when Kochia indica plants were irrigated every 4 weeks. Also, Reiad et al., (2005) found that prolonging or shortening irrigation intervals than four weeks tended to cut down forage yield of Kochia indica plants.

\subsection{Effect of irrigation intervals on chemical content}

The response of some chemical contents of Periploca angustifolia leaves and stems to different irrigation intervals in both experimentation years namely 2017-2018/ 2018-2019 under Baloza conditions is presented in Table (2).

It was noticed that all chemical constituents tested (protein \%, carbohydrates \%, Lipids \%, Ash \% and $\mathrm{k}$ ) were responded significantly and negatively with increasing irrigation intervals (Table 2). This trend was noticed in both leaves and stems except carbohydrates \% and $\mathrm{K}$ content in the stems and protein in the leaves were markedly increased by prolonging the period between irrigations. It could be concluded that water deficit affected negatively most chemical constituents of leaves and stems. This may be attributed to the higher soil moisture stress which decreased the amounts of metabolites synthesized by leaves that were decreased and been reflected in chemical composition of $P$. angustifolia plants. The present data could be substantiated by those reported by Kheraishi et al. (2004), Reiad et al. (2005) and Abd El-Maboud et al. (2018).

\subsection{Effect of cutting height on growth parameters and total chlorophyll}

Data in table (3) showed that some vegetative growth traits were unaffected significantly by raising cutting height from 30 to $60 \mathrm{~cm}$ from the ground level. Nevertheless, plant fresh weight, leaf area and total chlorophyll were increased significantly as cutting height increased only in the second one.These increments which observed in some vegetative growth parameters studied can be attributed to that cutting stimulated growth of the buds of the lower nodes of the stems and encourage the production of branches on the stump which contains large number of nodes and lateral buds in case of high cutting. On the other hand, the high amount of carbohydrates stored in the stump accompanied with high clipping may account much for this observation. These findings agreed with that obtained by Reiad et al. (2005) on Pigeon pea plants and El-Houssini et al. (2002) on Atriplex canescens.

\subsection{Effect of cutting height on chemical content}

Data in table (4) indicate the effect of different levels of cutting height $(30$ and $60 \mathrm{~cm}$ ) on chemical composition of leaves and stems. It is obvious from the obtained results that raising cutting height from 30 to $60 \mathrm{~cm}$ had an increase in carbohydrate in leaves and protein and lipids in stems. On the other hand raising cutting height had a reduction of protein and $\mathrm{K}$ contents in leaves and carbohydrate in stems. Such increments were significant for all chemical contents of leaves and stems except for lipids in the leaves and ash percentages for either the leaves or the stems where the differences between means of lipids and ash percentages due to cutting height were not great enough to reach the significance level as 
Middle East J. Agric. Res., 10(4): 1055-1062, 2021

Table 1: Response of growth parameters and total chlorophyll to irrigation intervals

\begin{tabular}{|c|c|c|c|c|c|c|c|c|}
\hline $\begin{array}{c}\text { Irrigation intervals } \\
\text { (weeks) }\end{array}$ & $\begin{array}{c}\text { Plant height } \\
/ \mathrm{cm}\end{array}$ & $\begin{array}{c}\text { Crown cover } \\
/ \mathbf{m}^{2} \\
\end{array}$ & $\begin{array}{c}\text { Crown volume } \\
/ \mathbf{m}^{3}\end{array}$ & $\begin{array}{l}\text { No. of branches } \\
\text { / plant }\end{array}$ & $\begin{array}{c}\text { Plant fresh } \\
\text { weight / g }\end{array}$ & $\begin{array}{l}\text { Plant dry } \\
\text { weight / g }\end{array}$ & $\begin{array}{c}\text { Leaf area } \\
\mathrm{cm}^{2}\end{array}$ & $\begin{array}{c}\text { Total chlorophyll } \\
\text { (spam) }\end{array}$ \\
\hline \multicolumn{9}{|c|}{ Cut I } \\
\hline 2 & $111.8 \mathrm{a}$ & $2.206 \mathrm{a}$ & $0.527 \mathrm{a}$ & $124.7 \mathrm{a}$ & $440.7 \mathrm{a}$ & $193.2 \mathrm{a}$ & $4.127 \mathrm{a}$ & $66.32 \mathrm{a}$ \\
\hline 3 & $127.7 \mathrm{a}$ & $1.765 \mathrm{a}$ & $0.473 \mathrm{a}$ & $87.33 \mathrm{ab}$ & $306.2 \mathrm{ab}$ & $155.2 \mathrm{ab}$ & $3.523 \mathrm{a}$ & $67.63 \mathrm{a}$ \\
\hline 4 & $129.0 \mathrm{a}$ & $1.273 \mathrm{a}$ & $0.363 \mathrm{a}$ & $54.83 \mathrm{~b}$ & $172.0 \mathrm{~b}$ & $96.00 \mathrm{~b}$ & $3.310 \mathrm{a}$ & $60.65 \mathrm{a}$ \\
\hline \multicolumn{9}{|c|}{ Cut II } \\
\hline 2 & $123.8 \mathrm{a}$ & $2.083 \mathrm{a}$ & $0.538 \mathrm{a}$ & $121.0 \mathrm{a}$ & $439.3 \mathrm{a}$ & $188.8 \mathrm{a}$ & $4.117 \mathrm{a}$ & $66.98 \mathrm{ab}$ \\
\hline 3 & $128.0 \mathrm{a}$ & $2.355 \mathrm{a}$ & $0.643 \mathrm{a}$ & $94.33 \mathrm{a}$ & $290.0 \mathrm{a}$ & $150.0 \mathrm{a}$ & $3.402 \mathrm{~b}$ & $73.77 \mathrm{a}$ \\
\hline 4 & $132.7 \mathrm{a}$ & $1.513 \mathrm{a}$ & $0.437 \mathrm{a}$ & $52.17 \mathrm{~b}$ & $167.3 \mathrm{a}$ & $94.67 \mathrm{a}$ & $3.492 \mathrm{~b}$ & $61.86 \mathrm{~b}$ \\
\hline \multicolumn{9}{|c|}{ Cut III } \\
\hline 2 & $146.3 \mathrm{a}$ & $1.512 \mathrm{~b}$ & $0.471 \mathrm{a}$ & $69.50 \mathrm{a}$ & $527.5 \mathrm{c}$ & $268.3 \mathrm{~b}$ & $3.860 \mathrm{a}$ & $59.78 \mathrm{a}$ \\
\hline 3 & $127.5 \mathrm{a}$ & $1.433 \mathrm{~b}$ & $0.399 \mathrm{a}$ & $59.83 \mathrm{a}$ & $779.0 \mathrm{~b}$ & $373.3 \mathrm{~b}$ & $3.227 \mathrm{a}$ & $60.74 \mathrm{a}$ \\
\hline 4 & $134.0 \mathrm{a}$ & $2.594 \mathrm{a}$ & $0.766 \mathrm{a}$ & $79.17 \mathrm{a}$ & $1160 . \mathrm{a}$ & $563.3 \mathrm{a}$ & $3.453 \mathrm{a}$ & $55.64 \mathrm{a}$ \\
\hline
\end{tabular}

Means having similar letters in same column are not differ statistically at $\mathrm{P}=0.05$

Table 2: Effect of irrigation intervals on some chemical constituents of Periploca angustifolia leaves and stems (average of two years of experimentation)

\begin{tabular}{|c|c|c|c|c|c|c|c|}
\hline \multirow{2}{*}{ Chemical content } & \multirow[t]{2}{*}{ Irrigation intervals (weeks) } & 2 & 3 & 4 & 2 & 3 & 4 \\
\hline & & \multicolumn{3}{|c|}{ Leaves } & \multicolumn{3}{|c|}{ Stems } \\
\hline Protein \% & & $6.512 \mathrm{~b}$ & $7.545 \mathrm{a}$ & $6.718 \mathrm{~b}$ & $3.143 \mathrm{a}$ & $2.777 \mathrm{~b}$ & $2.533 \mathrm{c}$ \\
\hline Carbohydrates contents & & $47.28 \mathrm{a}$ & $40.75 \mathrm{c}$ & $41.80 \mathrm{~b}$ & $49.07 \mathrm{~b}$ & $45.85 \mathrm{c}$ & $51.94 \mathrm{a}$ \\
\hline Lipids \% & & $1.883 \mathrm{a}$ & $0.6967 \mathrm{~b}$ & $0.370 \mathrm{c}$ & $3.017 \mathrm{~b}$ & $3.672 \mathrm{a}$ & $2.868 \mathrm{c}$ \\
\hline Ash \% & & $11.69 \mathrm{a}$ & $11.92 \mathrm{a}$ & $11.91 \mathrm{a}$ & $3.873 \mathrm{a}$ & $3.347 \mathrm{c}$ & $3.615 \mathrm{~b}$ \\
\hline K content $(\mathbf{m g} / \mathbf{1 0 0 g})$ & & $360.8 \mathrm{a}$ & $252.7 \mathrm{c}$ & $294.3 \mathrm{~b}$ & $213.8 \mathrm{~b}$ & $217.2 \mathrm{~b}$ & $263.8 \mathrm{a}$ \\
\hline
\end{tabular}

Table 3: Effect of cutting height on growth parameters and total chlorophyll.

\begin{tabular}{|c|c|c|c|c|c|c|c|c|}
\hline $\begin{array}{c}\text { Height of } \\
\text { Cutting (cm) }\end{array}$ & $\begin{array}{c}\text { Plant height } \\
/ \text { cm }\end{array}$ & $\begin{array}{c}\text { Crown cover } \\
\qquad / \mathbf{m}^{2}\end{array}$ & $\begin{array}{c}\text { Crown volume } \\
\qquad / \mathbf{m}^{3}\end{array}$ & $\begin{array}{c}\text { No. of branches } \\
\text { / plant }\end{array}$ & $\begin{array}{l}\text { Plant fresh } \\
\text { weight } \\
\text { (g/plant) }\end{array}$ & $\begin{array}{c}\text { Plant } \\
\text { dry weight } \\
\text { (g/plant) }\end{array}$ & $\begin{array}{c}\text { Leaf area } \\
\left(\mathrm{cm}^{2}\right)\end{array}$ & $\begin{array}{c}\text { Total } \\
\text { chlorophyll } \\
\text { (span) }\end{array}$ \\
\hline \multicolumn{9}{|c|}{ Cut I } \\
\hline 30 & $119.4 \mathrm{a}$ & $1.675 \mathrm{a}$ & $0.429 \mathrm{a}$ & $104.7 \mathrm{a}$ & $375.7 \mathrm{a}$ & $179.4 \mathrm{a}$ & $3.656 \mathrm{a}$ & $63.42 \mathrm{a}$ \\
\hline 60 & $126.2 \mathrm{a}$ & $1.821 \mathrm{a}$ & $0.480 \mathrm{a}$ & $73.22 \mathrm{ab}$ & $236.9 \mathrm{a}$ & $116.8 \mathrm{ab}$ & $3.651 \mathrm{a}$ & $66.31 \mathrm{a}$ \\
\hline \multicolumn{9}{|c|}{ Cut II } \\
\hline 30 & $126.0 \mathrm{a}$ & $2.023 \mathrm{a}$ & $0.538 \mathrm{a}$ & $105.4 \mathrm{a}$ & $380.7 \mathrm{a}$ & $179.9 \mathrm{a}$ & $3.868 \mathrm{a}$ & $70.29 \mathrm{a}$ \\
\hline 60 & $130.3 \mathrm{a}$ & $1.944 \mathrm{a}$ & $0.541 \mathrm{a}$ & $72.89 \mathrm{a}$ & $217.1 \mathrm{~b}$ & $109.1 \mathrm{~b}$ & $3.472 \mathrm{~b}$ & $64.78 \mathrm{~b}$ \\
\hline \multicolumn{9}{|c|}{ Cut III } \\
\hline 30 & $137.0 \mathrm{a}$ & $1.823 \mathrm{a}$ & $0.532 \mathrm{a}$ & $63.78 \mathrm{a}$ & $795.9 \mathrm{a}$ & $422.2 \mathrm{a}$ & $3.529 \mathrm{a}$ & $58.50 \mathrm{a}$ \\
\hline 60 & $134.9 \mathrm{a}$ & $1.870 \mathrm{a}$ & $0.558 \mathrm{a}$ & $75.22 \mathrm{a}$ & $848.4 \mathrm{a}$ & $381.1 \mathrm{a}$ & $3.498 \mathrm{a}$ & $58.94 \mathrm{a}$ \\
\hline
\end{tabular}

Means having similar letters in same row are not differ statistically at $\mathrm{P}=0.05$ 
shown in table(4). In this regard El-Houssini et al. (2002) mentioned that there was a gradual and slight increase in crude protein and total ash percentages with increasing cutting height in Atriplex canescens plants.

Table 4: Effect of cutting height on chemical contents of leaves and stems.

\begin{tabular}{|c|c|c|c|c|}
\hline \multirow{3}{*}{$\begin{array}{l}\text { Cutting height } \\
\text { Chemical content }\end{array}$} & \multicolumn{2}{|c|}{ Cutting height } & \multicolumn{2}{|c|}{ Cutting height } \\
\hline & 30 & 60 & 30 & 60 \\
\hline & \multicolumn{2}{|c|}{ Leaves } & \multicolumn{2}{|c|}{ Stems } \\
\hline Protein (\%) & $7.092 \mathrm{a}$ & $6.758 \mathrm{~b}$ & $2.750 \mathrm{~b}$ & $2.886 \mathrm{a}$ \\
\hline Carbohydrates (\%) & $42.40 \mathrm{~b}$ & $44.16 \mathrm{a}$ & $52.00 \mathrm{a}$ & $45.91 \mathrm{~b}$ \\
\hline Lipids (\%) & $0.913 \mathrm{a}$ & $1.053 \mathrm{a}$ & $2.971 \mathrm{~b}$ & $3.400 \mathrm{a}$ \\
\hline Ash (\%) & $11.70 \mathrm{a}$ & $11.98 \mathrm{a}$ & $3.551 \mathrm{a}$ & $3.672 \mathrm{a}$ \\
\hline$K$ content $(\mathrm{mg} / 100 \mathrm{~g})$ & $321.4 \mathrm{a}$ & $283.8 \mathrm{~b}$ & $235.8 \mathrm{a}$ & $227.4 \mathrm{a}$ \\
\hline
\end{tabular}

Means having similar letters in same row are not differ statistically at $\mathrm{P}=0.05$

\subsection{Effect of the interaction between irrigation intervals and cutting height on growth parameters and total chlorophyll}

The interaction between the two main factors considered in this study (irrigation intervals and cutting height) had no statistical significant effect on plant height and No. of branches /plant. This trend was noticed in all cuts taken throughout the two experimentation years as shown in table (5).

On the other hand, crown cover, crown volume, leaf area and chlorophyll were responded significantly to that interaction (table 5). The highest value of crown cover was obtained whenplants were irrigated every four weeks and clipped at $60 \mathrm{~cm}$ stubble height in the third cut. Whereas, the maximum value of crown volume was obtained when irrigation intervals were every four weeks and the plants were cut at $60 \mathrm{~cm}$ above the ground surface. This was observed in the third cut.

The greatest values of leaf area $\left(4.247 \mathrm{~cm}^{2}\right)$ were achieved when plants were irrigated every two weeks and harvested at $30 \mathrm{~cm}$ in the third cut. While, the highest value of total chlorophyll (78.69) was obtained when the plants were irrigated every three weeks and clipped at the minimum level $(30 \mathrm{~cm})$.

\subsection{Effect of the interaction between irrigation intervals and Cutting height on chemical content}

Data presented in table (6) show the effect of the interaction between the two main factors under this study (irrigation intervals and cutting height) on the chemical contents produced from leaves and stems. Such effect was significant on both leaves and stems for all studied chemical contents (table 6). It seems from the data listed in table (6) that irrigation every three weeks and clipping at $30 \mathrm{~cm}$ act together to produce the highest percentage of protein and ash in leaves. However, the highest value of carbohydrates percentage in leaves was obtained when plants were irrigated every two weeks and clipped at $30 \mathrm{~cm}$ above the ground level. At the same time, lipid \% in leaves gave its high value when the plants were irrigated every two weeks and cut at $60 \mathrm{~cm}$. Results in table (6) indicated also that irrigation intervals every two weeks by cutting height at $60 \mathrm{~cm}$ interaction exerted the highest values of both protein and ash percentages in stems. Moreover, higher values of carbohydrate percentage in stems were achieved by irrigated plants every four weeks and cut at the lowest level $(30 \mathrm{~cm})$. Lipids reached its highest value (3.83) when the plants were irrigated every three weeks and highest stubble height (60 $\mathrm{cm})$.

From the above results, $\mathrm{K}$ content and total carbohydrates are parallel together either in the leaves or in the stems. $\mathrm{K}^{+}$is engaged in Rubisco motivation causing upregulation of Rubisco activity (Tränkner et al., 2018). Indeed, $\mathrm{K}^{+}$activated carbohydrate metabolism and proline accumulation in tomato seedling roots that caused improvement in osmotic tolerance under salinity stress (Khan et al., 2021). 
Table 5: Effect of the interaction between irrigation intervals and cutting height on growth parameters and total chlorophyll.

\begin{tabular}{|c|c|c|c|c|c|c|c|c|c|}
\hline $\begin{array}{c}\text { Irrigation } \\
\text { intervals } \\
\text { (weeks) }\end{array}$ & $\begin{array}{c}\text { Cutting } \\
\text { height }(\mathrm{cm})\end{array}$ & $\begin{array}{c}\text { Plant height } \\
/ \mathrm{cm}\end{array}$ & $\begin{array}{c}\text { Crown } \\
\text { cover } / \mathbf{m}^{2}\end{array}$ & $\begin{array}{c}\text { Crown } \\
\text { volume } / \mathbf{m}^{3}\end{array}$ & $\begin{array}{c}\text { No. of } \\
\text { branches / } \\
\text { plant }\end{array}$ & $\begin{array}{l}\text { Plant fresh } \\
\text { weight / gm }\end{array}$ & $\begin{array}{c}\text { Plant dry } \\
\text { weight / gm }\end{array}$ & $\begin{array}{l}\text { Leaf area } \\
\qquad / \mathrm{cm}^{2}\end{array}$ & $\begin{array}{c}\text { Chlorophyll } \\
\text { (span) }\end{array}$ \\
\hline \multicolumn{10}{|c|}{ Cut I } \\
\hline \multirow{2}{*}{2} & 30 & $112.0 \mathrm{a}$ & $2.280 \mathrm{a}$ & $0.540 \mathrm{a}$ & $133.3 \mathrm{a}$ & $500.0 \mathrm{a}$ & $227.3 \mathrm{a}$ & $4.217 \mathrm{a}$ & $65.81 \mathrm{a}$ \\
\hline & 60 & $111.7 \mathrm{a}$ & $2.132 \mathrm{ab}$ & $0.513 a$ & $116.0 \mathrm{a}$ & $381.3 \mathrm{a}$ & $159.0 \mathrm{a}$ & $4.037 \mathrm{a}$ & $66.82 \mathrm{a}$ \\
\hline \multirow{2}{*}{3} & 30 & $117.0 \mathrm{a}$ & $1.756 \mathrm{ab}$ & $0.453 \mathrm{a}$ & $124.0 \mathrm{a}$ & $438.7 \mathrm{a}$ & $211.3 \mathrm{a}$ & $3.393 \mathrm{a}$ & $65.52 \mathrm{a}$ \\
\hline & 60 & $138.3 \mathrm{a}$ & $1.774 \mathrm{ab}$ & $0.493 \mathrm{a}$ & $50.67 \mathrm{a}$ & $173.7 \mathrm{a}$ & $99.00 \mathrm{a}$ & $3.653 \mathrm{a}$ & $69.73 \mathrm{a}$ \\
\hline \multirow{2}{*}{4} & 30 & $129.3 \mathrm{a}$ & $0.990 \mathrm{~b}$ & $0.293 \mathrm{a}$ & $56.67 \mathrm{a}$ & $188.3 \mathrm{a}$ & $99.67 \mathrm{a}$ & $3.357 \mathrm{a}$ & $58.92 \mathrm{a}$ \\
\hline & 60 & $128.7 \mathrm{a}$ & $1.556 \mathrm{ab}$ & $0.433 \mathrm{a}$ & $56.67 \mathrm{a}$ & $155.7 \mathrm{a}$ & $92.33 \mathrm{a}$ & $3.263 \mathrm{a}$ & $62.38 \mathrm{a}$ \\
\hline \multicolumn{10}{|c|}{ Cut II } \\
\hline \multirow{2}{*}{2} & 30 & $117.7 \mathrm{a}$ & $2.144 \mathrm{a}$ & $0.518 \mathrm{a}$ & $132.7 \mathrm{a}$ & $555.0 \mathrm{a}$ & $238.0 \mathrm{a}$ & $4.093 \mathrm{a}$ & $70.83 \mathrm{ab}$ \\
\hline & 60 & $130.0 \mathrm{a}$ & $2.022 \mathrm{a}$ & $0.557 \mathrm{a}$ & $109.3 \mathrm{a}$ & $323.7 \mathrm{ab}$ & $139.7 \mathrm{ab}$ & $4.140 \mathrm{a}$ & $63.12 \mathrm{~b}$ \\
\hline \multirow{2}{*}{3} & 30 & $124.3 \mathrm{a}$ & $2.419 \mathrm{a}$ & $0.642 \mathrm{a}$ & $126.7 \mathrm{a}$ & $390.7 \mathrm{ab}$ & $194.0 \mathrm{ab}$ & $3.883 \mathrm{ab}$ & $78.69 \mathrm{a}$ \\
\hline & 60 & $131.7 \mathrm{a}$ & $2.291 \mathrm{a}$ & $0.645 \mathrm{a}$ & $62.00 \mathrm{a}$ & $189.3 \mathrm{~b}$ & $106.0 \mathrm{~b}$ & $2.920 \mathrm{c}$ & $68.85 \mathrm{~b}$ \\
\hline \multirow{2}{*}{4} & 30 & $136.0 \mathrm{a}$ & $1.507 \mathrm{a}$ & $0.453 \mathrm{a}$ & $57.00 \mathrm{a}$ & $196.3 \mathrm{~b}$ & $107.7 \mathrm{~b}$ & $3.627 \mathrm{ab}$ & $61.34 \mathrm{~b}$ \\
\hline & 60 & $129.3 \mathrm{a}$ & $1.520 \mathrm{a}$ & $0.422 \mathrm{a}$ & $47.33 \mathrm{a}$ & $138.3 \mathrm{~b}$ & $81.67 \mathrm{~b}$ & $3.357 \mathrm{bc}$ & $62.38 \mathrm{~b}$ \\
\hline \multicolumn{10}{|c|}{ Cut III } \\
\hline \multirow{2}{*}{2} & 30 & $154.3 \mathrm{a}$ & $1.426 \mathrm{~b}$ & $0.472 b c$ & $65.00 \mathrm{a}$ & $572.0 \mathrm{a}$ & $311.7 \mathrm{a}$ & $4.247 \mathrm{a}$ & $56.87 \mathrm{a}$ \\
\hline & 60 & $138.3 \mathrm{a}$ & $1.598 \mathrm{~b}$ & $0.470 \mathrm{bc}$ & $74.00 \mathrm{a}$ & $483.0 \mathrm{a}$ & $225.0 \mathrm{a}$ & $3.373 b c$ & $6269 \mathrm{a}$ \\
\hline \multirow{2}{*}{3} & 30 & $130.0 \mathrm{a}$ & $1.535 \mathrm{~b}$ & $0.423 \mathrm{c}$ & $49.00 \mathrm{a}$ & $713.0 \mathrm{a}$ & $378.3 \mathrm{a}$ & $3.403 \mathrm{bc}$ & $63.35 \mathrm{a}$ \\
\hline & 60 & $125.0 \mathrm{a}$ & $1.332 \mathrm{~b}$ & $0.374 \mathrm{c}$ & $70.67 \mathrm{a}$ & $845.0 \mathrm{a}$ & $368.3 \mathrm{a}$ & $3.050 \mathrm{c}$ & $58.12 \mathrm{a}$ \\
\hline \multirow{2}{*}{4} & 30 & $126.7 \mathrm{a}$ & $2.508 \mathrm{a}$ & $0.701 \mathrm{ab}$ & $77.33 \mathrm{a}$ & 1103. a & $576.7 \mathrm{a}$ & $2.937 \mathrm{c}$ & $55.29 \mathrm{a}$ \\
\hline & 60 & $141.3 \mathrm{a}$ & $2.680 \mathrm{a}$ & $0.830 \mathrm{a}$ & $81.00 \mathrm{a}$ & 1217. a & $550.0 \mathrm{a}$ & $3.970 \mathrm{~b}$ & $56.00 \mathrm{a}$ \\
\hline
\end{tabular}


Table 6: Effect of the interaction between irrigation intervals and cutting height on chemical contents of leaves and stems.

\begin{tabular}{|c|c|c|c|c|c|c|}
\hline \multirow{4}{*}{ Chemical content } & \multicolumn{6}{|c|}{ Irrigation intervals (weeks) } \\
\hline & & & \multirow{2}{*}{\multicolumn{2}{|c|}{$\frac{3}{\text { Cutting height }(\mathrm{cm})}$}} & \multirow{2}{*}{\multicolumn{2}{|c|}{$\begin{array}{c}4 \\
\text { Cutting height }(\mathrm{cm})\end{array}$}} \\
\hline & \multicolumn{2}{|c|}{ Cutting height (cm) } & & & & \\
\hline & 30 & 60 & 30 & 60 & 30 & 60 \\
\hline \multicolumn{7}{|c|}{ At leaves } \\
\hline Protein (\%) & $6.617 \mathrm{~cd}$ & $6.407 \mathrm{~d}$ & $8.290 \mathrm{a}$ & $6.800 \mathrm{bc}$ & $6.370 \mathrm{~d}$ & $7.067 \mathrm{~b}$ \\
\hline Carbohydrates (\%) & $49.63 \mathrm{a}$ & $44.94 \mathrm{c}$ & $40.08 \mathrm{e}$ & $41.42 \mathrm{~d}$ & $37.49 \mathrm{f}$ & $46.11 \mathrm{~b}$ \\
\hline Lipids (\%) & $1.803 \mathrm{a}$ & $1.963 \mathrm{a}$ & $0.677 \mathrm{~b}$ & $0.717 \mathrm{~b}$ & $0.260 \mathrm{c}$ & $0.480 \mathrm{bc}$ \\
\hline $\operatorname{Ash}(\%)$ & $10.73 \mathrm{c}$ & $12.65 \mathrm{a}$ & $12.88 \mathrm{a}$ & $10.97 \mathrm{bc}$ & $11.50 \mathrm{~b}$ & $12.32 \mathrm{a}$ \\
\hline$K$ content $(\mathbf{m g} / \mathbf{1 0 0 g})$ & $405.7 \mathrm{a}$ & $316.0 \mathrm{~b}$ & $276.0 \mathrm{c}$ & $229.3 \mathrm{~d}$ & $282.7 \mathrm{c}$ & $306.0 \mathrm{bc}$ \\
\hline \multicolumn{7}{|c|}{ At stems } \\
\hline Protein (\%) & $3.023 \mathrm{~b}$ & $3.263 \mathrm{a}$ & $2.817 \mathrm{c}$ & $2.737 \mathrm{c}$ & $2.410 \mathrm{~d}$ & $2.657 \mathrm{c}$ \\
\hline Carbohydrates (\%) & $53.58 \mathrm{a}$ & $44.55 \mathrm{c}$ & $48.64 \mathrm{~b}$ & $43.05 \mathrm{c}$ & $53.76 \mathrm{a}$ & $50.11 \mathrm{~b}$ \\
\hline Lipids (\%) & $2.573 \mathrm{~d}$ & $3.460 \mathrm{~b}$ & 3.510 & $3.833 \mathrm{a}$ & $2.830 \mathrm{c}$ & $2.907 \mathrm{c}$ \\
\hline Ash \% & $3.533 \mathrm{bc}$ & $4.213 \mathrm{a}$ & $3.433 \mathrm{bc}$ & $3.260 \mathrm{c}$ & $3.687 \mathrm{~b}$ & $3.543 \mathrm{bc}$ \\
\hline$K$ content $(\mathrm{mg} / \mathbf{1 0 0 g})$ & $228.0 \mathrm{~b}$ & $99.7 \mathrm{c}$ & $213.0 \mathrm{bc}$ & $221.3 \mathrm{~b}$ & $266.3 \mathrm{a}$ & $261.3 \mathrm{a}$ \\
\hline
\end{tabular}

Means having similar letters in same column are not differ statistically at $\mathrm{P}=0.05$

\section{References}

Abd El-Maboud M.M., 2016. Mechanisms of drought tolerance in Cornulaca monacantha Del. Journal of Environmental Sciences, 45: 175-186.

Abd El-Maboud, M.M., A.A. Elhenawy and M.F. Ibrahim, 2018. Biochemical responses of Wolfbeane (Periploca angustifolia Labill) to water stress . International Journal of Plant \& Soil Science 24(6); 1-9, 2018, Article no. IJPSS, 44540.

Association of Official Analytical Chemists, Association of Official Agricultural Chemists (US), 1990. Official methods of analysis of the association of official analytical chemists $\left(15^{\text {th }} \mathrm{ed}\right.$.). Washington D.C: Association of Official Analytical Chemists.

Castro, J., R. Zamara, I.A. Ho'dar, and J.M. Go'mez, 2002. Use of shrubs as nurse plants: a new technique for reforestation in Mediterranean mountains. Restoration ecology, 10 (2): 297-305.

Chaplin, M.F., and J.F. Kennedy 1994. Carbohydrate analysis: A practical approach. 2nd Ed. Oxford Univ., Press Oxford, New York, Tokyo.

Dghim, F., R. Abdellaoui, M. Boukhris, M. Neffati and M. Chaieb, 2018. Physiological and biochemical changes in Periploca angustifolia plants under withholding irrigation and re watering conditions. South African J. of Botany, 114: 241-249.

Duncan, D.B., 1955. Multiple range and multiple (F) tests. Biometerics, 11:1-42

El-Houssini, A.A., S.A. Khalifa and Zeinab M. Nassar, 2002. Forage yield of four wing saltbush (Atriplex canscens James) as affected by cutting Management under South Sinai conditions. Annals Agric. Sci., Ain Shams Univ., Cairo, 47 (2): 611-620.

El-Houssini, A.A., 2007. Response of some leguminous pasture species to phosphorus fertilization levels under new reclaimed soil conditions. Annals of Agric. Sc., Moshtohor, 45(1): 93-100.

Ferchichi, A., 1995. Caracterisation morphobiologique et e'cologique d'une espece pastrole de la tunisie presahrienne (Periploca angustifolia Labill.) - Implications pour Lamelioration pastorale. Cahiers Options Me'diterrane'ennes, 12: 1- 13.

Foyer, C.H. and G. Noctor, 2000. Oxygen processing in photosynthesis: regulation and signaling. New Phytologist, 146: 359-388.

Heneidy, S.Z., 2002. Role of indicator range species as browsing forage and effective nutritive source, in Matrouh area, a Mediterranean Coastal region, NW- Egypt. Journal of Biological Sciences, 2(2): 136-142.

Khan, M.N., S. Mukherjee, A.A. Al-Huqail, R.A. Basahi, H.M. Ali, B.M.A. Al-Munqedhi, M.H. Siddiqui, and H.M. Kalaji, 2021. Exogenous potassium $\left(\mathrm{K}^{+}\right)$positively regulates $\mathrm{Na}^{+} / \mathrm{H}^{+}$antiport system, carbohydrate metabolism, and ascorbate-glutathione cycle in $\mathrm{H}_{2} \mathrm{~S}$-dependent manner in $\mathrm{NaCl}$-stressed tomato seedling roots. Plants 2021, 10, 948. https://doi.org/ 10.3390/plants 10050948 . 
Kheraishi, A.H., M.Sh. Reiad, M. Yassin and A.A. El- Houssini, 2004. Growth response of Kochia indica wight to irrigation water salinity level, Moisture stress and cutting intervals. Zagazig J. Agric. Res., 31 (3): 829- 842.

Reiad, M.Sh., M. Yassin, A.A. El- Houssini and A.H. Kheraishi, 2005. Response of Kochia forage yield to some crop management system under South Sinai conditions. The $11^{\text {th }}$ Conference of Agronomy, Agron. Dept., Fac. Agric., Assiut Univ.

Reiad, M.Sh., Nemat A. Nour El-Din, H.M. Abd El-Aziz and A.A. El-Houssini, 2001. Pigeon pea forage yield as affected by phosphorus rates, sowing date and cutting height. Proceeding of the Annual Conference " Sustainable Agricultural Development" 28-30, fayoum.

Snedecor, G.W. and W.G. Cochran, 1980. Statistical method. $7^{\text {th }}$ ed. Pp.225-269. Iowa State Univ., Press Amen, Iowa, U.S.A.

Thalen, D.C.P., 1978. Ecology and utilization of desert shrub range lands in Iraq. Dr. W. Junk, P. R. Publishers, the Hegue.

Tränkner, M., E. Tavakol, and B. Jákli, 2018. Functioning of potassium and magnesium in photosynthesis, photosynthate translocation and photoprotection. Physiologia Plantarum, 163, 414-431. doi:10.1111/ppl.12747.

Tripathi, R.D., G.P. Srivastava, M.S. Micra and S.C. Pandey, 1971. Protien cotent in some varieties of legumes. The Allah Abad Former, 16: 291-294.

Yoshida, S., D.A. Frono, J.H. Cook, and K.A. Gomez, 1976. Laboratory manual for physiological studies of rice ( $3^{\text {rd }}$ ed.). Los Ban os: The International Rice Research Institute. 